Dokuz Eylül Üniversitesi-Mühendislik Fakültesi Fen ve Mühendislik Dergisi Cilt 20, Sayı 58, Ocak, 2018
Dokuz Eylul University-Faculty of Engineering Journal of Science and Engineering Volume 20, Issue 58, January, 2018

DOI: $10.21205 /$ deufmd. 2018205820

\title{
A Prospect on Integration of Solar Technology to Modern Greenhouses
}

\author{
Günnur KOÇAR ${ }^{* 1}$, Ahmet ERYAŞAR ${ }^{1}$, Elif GÖDEKMERDAN1, \\ Sevim ÖZGÜL1, Mert DÜZENL'் ${ }^{1}$ \\ ${ }^{1}$ Ege Üniversitesi, Güneș Enerjisi Enstitüsü, 35100, İzmir \\ ORCID: 0000-0003-1142-8574 - ORCID: 0000-0003-4865-4049 - ORCID: 0000-0002- \\ 7963-6321 - ORCID: 0000-0002-0210-0393 - ORCID: 0000-0002-7265-165X
}

(Alınış / Received: 09.10.2017, Kabul / Accepted: 27.11.2017, Online Yayınlanma / Published Online: 20.01.2018)

Keywords Solar Technology, Modern Greenhouse, Current Status

\begin{abstract}
The demand for food products is increasing with the growing world population day by day. Given the environmental and land deterioration, agricultural requirement cannot be supply with conventional agriculture. At this point modern greenhouses are attractive alternatives. The high energy consumption of greenhouse systems is a major obstacle to sustainable production. With integration of solar technology to modern greenhouses is aimed to reduce dependence on fossil fuels and expanding the greenhouse in places where greenhouse activities are not carried out. In this study, the current state of solar technology applied in the modern greenhouses has been examined. This study reviews the modern solar greenhouse application technologies which are mainly renewable and sustainable based solutions such as photovoltaic (PV) modules, CSP and hybrid PV/T system. Also, it is summarized what purpose these technologies are used for in the greenhouse. In addition, advantages of solar technology applied to modern greenhouses have been determined.
\end{abstract}

\section{Güneș Enerjisi Teknolojisinin Modern Seralara Entegrasyonu Üzerine Bir İnceleme}

Anahtar Kelimeler Özet: Dünya nüfusunun artışıyla birlikte gün geçtikçe gıda Güneş Teknolojisi, Modern Sera, Mevcut Durum ürünlerine olan talep de artmaktadır. Çevresel tahribatlar ve tehditler göz önüne alındığında, tarımsal ihtiyaç geleneksel tarımla tedarik edilemediği görülmektedir. Bu noktada modern seralar çekici bir alternatif durumundadır. Sera sistemlerinin yüksek enerji tüketimi, sürdürülebilir üretim için büyük bir engel teşkil etmektedir. Güneş enerjisinin modern seralara entegrasyonu ile fosil yakıtlara bağımlılı̆̆ın azaltılması ve seracılık faaliyetlerinin gerçekleștirilmediği yerlerde seranın yaygınlaştırılması amaçlanmaktadır. $\mathrm{Bu}$ çalışmada modern seralarda uygulanan güneş enerjisi teknolojisi üzerine bir inceleme yapılmıştır. Bu çalışmada; esas olarak fotovoltaik (FV) modüller, CSP ve hibrid FV / T sistemi gibi yenilenebilir ve sürdürülebilir temelli çözümlerden oluşan güneș teknolojilerinin modern seralarda uygulamaları gözden geçirilmiştir. Ayrıca modern seralara uygulanan güneş enerjisi teknolojisinin avantajları belirlenmiştir. 


\section{Introduction}

The demand of food products is increasing with human population and conventional agriculture cannot supply food requirement with this acceleration. The increase of agricultural activities becomes mandatory while environmental problems such as human activities, urbanization, climate change desertification, deforestation and salinization have threatened agricultural productivity and food safety [1]. Additionally, there is an important question must be addressed: With the current population at seven billion and rising, what is the most sustainable and cost effective way to feed the world's population? Sustainable agriculture is gaining importance as the production of high-quality products in an economical way with eco-friendly techniques. Modern greenhouses are one of the areas where sustainable agriculture is applied [2]. The control of the growth environment in terms of light, water, temperature, relative humidity, $\mathrm{CO}_{2}$ concentration, and ventilation improves the yield and quality of crops in greenhouse plant production. In other words, greenhouse provides that optimal growth conditions for plants [3]. There are numerous interrelated parameters that could influence the environmental parameters in greenhouses such as the size of the greenhouse, its location, the type of covering material, heat storage method, quantity and quality of materials used, type of cultivation, desired day and night temperature of the inside air, and outside ambient conditions [4]. While providing optimal growth conditions for plants in greenhouse, heating and cooling systems is gaining importance. It has been confirmed that optimal temperature range for plant in greenhouse is between 22 and $28{ }^{\circ} \mathrm{C}$ in the day time and $15-20{ }^{\circ} \mathrm{C}$ at night. when the temperatures is below $12{ }^{\circ} \mathrm{C}$ or above $30{ }^{\circ} \mathrm{C}$, the yield and quality of greenhouse plants can easily affect negatively [5]. In this case heating and cooling systems are two major costs involved in greenhouses production. Usually greenhouse heating is provided by fossil fuels such as diesel, fuel oil, liquid petroleum, gas which cause high carbon dioxide $\left(\mathrm{CO}_{2}\right)$ emission, or by using electric heaters, which consume more energy. For instance, the cost of a greenhouse in Turkey heated by coal is calculated by Canakci et al. And the total annual cost per ha could be as high as 65,891.5-151,220.6 \$/year [6]. The Government of Canada make an approximate calculation of energy needs and cost required by a $496 \mathrm{~m}^{2}$ greenhouse with a conversion efficiency of $70 \%$. Assuming typical energy required by a double poly greenhouse is $2100 \mathrm{MJ} / \mathrm{m}^{2}$, the need for heating during September to May is calculated. The cost of the energy needed is determined to be $\$ 22,126.56 /$ season for propane, $\$ 17,355.04 /$ season for electricity, $\$ 14,880.00 /$ season for fuel oil and $\$ 10,207.68 /$ season for natural gas [5].

Tong et al. carried out an experiment in Japan and reported that the hourly energy consumption for heating from January to March in the greenhouse with heat pumps was in the range of 0.22 to $0.56 \mathrm{MJ} \mathrm{m}^{-2}$, while heating with a kerosene heater was in the range of $0.42-0.76 \mathrm{MJ} \mathrm{m}^{-2}$. As well, the hourly $\mathrm{CO}_{2}$ emissions in the greenhouse with heat pumps were in the range of 9.5$24 \mathrm{~g} \mathrm{~m}^{-2}$, while that in the greenhouse with the kerosene heater was in the range of 31-55 $\mathrm{g} \mathrm{m}^{-2}$ [7].

As seen in the above examples, the energy consumption and the emissions of $\mathrm{CO}_{2}$ are too high. At this point, it become mandatory to find an alternative for sustainable greenhouse production. Solar energy which provides many benefits such as reduce 
both $\mathrm{CO}_{2}$ emissions and heating costs is the main source of renewable energies applied in agricultural. Although solar energy technologies have a relatively high initial cost, it also has many advantages which are without fuel, low carbon emission, long term solar resources, less payback time, and little maintenance [4]. With solar energy, sustainable agriculture which pays more attention to food, environment and energy is possible.

In the last few decades, government policies supportive of renewable energy development and utilization. In this direction, many countries focused of incentives that $\mathrm{PV}$ power generation for agricultural crop production [4]. One of the best examples, the city of Almeria in Spain which has greenhouses with 26.000 hectares and also, it has the largest concentration of greenhouses in the world. More than half of the Europe's demand for fresh fruits and vegetables are grown under the plastic shades, fueling the province of Almeria's economy by $\$ 1.5$ billion in annual revenue [8]. Another example of the application of renewable energy in agriculture is seen in China. The total PV market size in agriculture has more than $4 \mathrm{GW}$ and will be up to $15 \mathrm{GW}$ in 2020 [9].

This study reviews the modern solar greenhouse application technologies which are mainly renewable and sustainable based solutions such as photovoltaic (PV) modules, CSP and hybrid PV/T system.

\section{Solar Technology for Modern Greenhouse}

One of purposes of utilization of PV in greenhouse is to obtain higher agricultural income by creating optimal environment for crops growth. To create optimal conditions for plant growth and development, the greenhouses which exploits the radiation coming from the sun can be used as a solar collector. The short waves of solar irradiation can enter the greenhouse by passing through cover materials (plastic, glass and fiberglass). The solar radiation inside the greenhouse depends on incident radiation on the ground, shape and orientation of the greenhouse, type of structure, transmittance, absorption, and reflection of the covering material, size and position of the opaque structure, dust on the cover, cover condensation. These parameters protect crop from adverse weather conditions and provide optimum growing conditions for plants [10]. Furthermore, modern solar greenhouse application technologies which are mainly renewable and sustainable based solutions such as photovoltaic (PV) modules, CSP and hybrid PV/T system are widely preferred technologies.

\subsection{PV Greenhouse}

Integrating transparent and semitransparent PV panels on greenhouses that can provide increasing the amount of sunlight to enter the greenhouse. Moreover, by using selective plastic films can provide suitable wavelengths of light absorption for growth of different plants [3]. Also, the supplemental lighting which powered by PV energy can integrate with natural radiation [9], or LED lamp which powered by PV energy can be used in night to provide light for plant growth [11].

Using PV in greenhouse, provide that decreasing carbon dioxide $\left(\mathrm{CO}_{2}\right)$ emission and producing electricity. PV modules are highly considered in novel greenhouse applications to supply heating, cooling, ventilation and lighting to the greenhouse in an eco-friendly way [12]. 
Solar photovoltaic (PV) cells to supply electricity for greenhouse climate control. If the electrical energy consumed by some heavy loads, such as heating and cooling, could be replaced or partly replaced with PV generated energy, then consumption of power-line electricity in greenhouses could be greatly reduced. Of course, the excess electricity from PV generation can be sold to government by connecting to the electric grid [5].

If there is a lack of land near a greenhouse, greenhouse roofs are an attractive location for PV-array mounting. The PV-array formations are straight-line and checkerboard. The distribution of sunlight in the greenhouse is greatly modified by the PV-array arrangements without reducing electrical energy production. The quality and quantity of product can be affected by shading and geometrical PV array. The balance between the amount of electricity production and allowable shading are expected to vary according to the plant species, geography, meteorology, season, and greenhouse characteristics. Nevertheless, the roof mounting of a PV array inevitably casts a shadow on plants in the greenhouse [13]. Crop yields depend strongly on the availability of light. Nearly $1 \%$ yield loss is expected to occur with a $1 \%$ reduction in light [14]. The large PV array is undesired that it causes large shading area because the main purpose of greenhouses is plant production. [13]. Yano et al. [15] studied electricity gain and shading in an east-west oriented greenhouse which's roof area was covered by $12.9 \% \mathrm{PV}$ array which has $720 \mathrm{~W}$ maximum-rated-power. Two PV array configurations which were straight-line and checkerboard arrangements were tested. The two arrangements composed quite different sunlight distributions in the greenhouse. By means of intermittently array of checkerboard PV the annual solar-irradiation distribution in greenhouse was more uniform than that of the straight-line PV. Kadowaki et al. [13] studied how plants grow can be affected by the equipped of PV arrays in the greenhouse. The straight-line arranged PV array shadows inhibited the growth of welsh onions because of shadows on the plants continuously during cultivation. However, using the checkerboard array the inhibitory growth effects of the shading were diminished. Ureña-Sánchez et al. [14] tested PV modules with a checkerboard arrangement for greenhouse tomato production with nearly $10 \%$ coverage. The experiences in the integration of PV and greenhouse carried out in South Eastern Spain. The results indicated that the yearly electricity production normalized to the greenhouse ground surface was $8.25 \mathrm{kWh} \mathrm{m}^{-2}$ and $\mathrm{PV}$ shading did not affect the yield or the price of tomatoes despite some negative effects on fruit size and colour. Kadowaki et al. studied effect of shading on greenhouse which emerged using PV modules. The fresh and dry-weight of welsh onion was observed under a 13\% PV roof coverage. The result indicated that crop yield was lossed average $25 \%$. Minuto et al. studied that the effects of PV area roof on basil and cucumber in the greenhouse and they indicated that there were no significant effects on biomass production and yield when the PV area was lower than $20 \%$.

Table 1 shows type of PV used on greenhouse for heating, cooling and lighting [17]. 
Table 1. Types of PVs used on greenhouses for heating, cooling and lighting [17].

\begin{tabular}{|c|c|c|}
\hline Type of PV & Country & Result \\
\hline Semi-transparent c-Si & India & The highest electrical energy is $1.9 \mathrm{kWh} /$ day. \\
\hline $\begin{array}{l}\text { Semi-transparent c-Si, } \\
\text { spherical solar } \\
\text { microcells }\end{array}$ & Japan & $\begin{array}{l}\text { The peak power output is } 540 \mathrm{~mW} \text { for solar } \\
\text { intensity of with } 1223 \mathrm{~W} / \mathrm{m}^{2} \text { the conversion } \\
\text { efficiency is } 4.5 \% \text {. }\end{array}$ \\
\hline c-Si solar cells & India & $\begin{array}{l}\text { The peak power is } 3825 \mathrm{~W} \text {. The module strengthens } \\
\text { the viability of a greenhouse grid-independent. }\end{array}$ \\
\hline c-Si solar cells & India & $\begin{array}{l}\text { The annual overall electrical energy savings is } 1185 \\
\mathrm{~kW} \text { h. Electricity production factor (EPF) is } 2.04 \text {. }\end{array}$ \\
\hline m-Si solar cells & Italy & $\begin{array}{l}\text { Energy saving is approximately } 30 \% \text { for summer } \\
\text { cooling and } 11 \% \text { for winter heating. }\end{array}$ \\
\hline m-Si solar cells & Netherlands & $\begin{array}{l}\text { Annual electrical energy is expected to be } 29 \\
\mathrm{kWh} / \mathrm{m}^{2} \text {. Energy conversion efficiency of the system } \\
\text { is } 11 \% \text {. }\end{array}$ \\
\hline p-Si solar cells & Turkey & $\begin{array}{l}\text { Total electricity based energy consumption is } 8.10 \\
\mathrm{kWh} / \text { day. } 34.55 \% \text { is provided from PV cells, others } \\
\text { from grid. Temperature inside the greenhouse could } \\
\text { be decreased by } 19.9^{\circ} \mathrm{C} \text {. }\end{array}$ \\
\hline Multi c-Si solar cells & Italy & $\begin{array}{l}\text { The annual electricity production is } 107,885 \mathrm{kWh} \text {. } \\
\text { The overall conversion efficiency of the PV system is } \\
11.4 \% \text {. Yearly average temperature inside the } \\
\text { greenhouse } 19.8^{\circ} \mathrm{C} \text { and the range is } 12-30^{\circ} \mathrm{C} \text {. }\end{array}$ \\
\hline a-Si thin film & Spain & $\begin{array}{l}\text { Electricity production is } 8.25 \mathrm{kWh} / \mathrm{m}^{2} \text { with roof } \\
\text { coverage ratio of } 9.79 \% \text {. }\end{array}$ \\
\hline a-Si solar cells & Japan & $\begin{array}{l}\text { The straight-line PV arrays generate electricity of } \\
4.08 \mathrm{GJ} / \text { year. Electrical energy generation using PV } \\
\text { cells is valid for use in sustainable greenhouse crop } \\
\text { production }\end{array}$ \\
\hline
\end{tabular}

Thanks to ease of access, durability against unfavorable weather conditions, improving efficiency, and more affordable price, conventional PV modules have various advantages. The energy which is obtained from conventional PV modules can be directly used for DC devices or transformed to AC by inverters and can be stored in batteries as used for AC devices. Requirement of electricity of any machinery such as lamp, heater, cooler, pump in greenhouse can be supplied by batteries. Also, obtained electricity from conventional PV modules is used for artificial heater and lighting in greenhouse applications [17]. On the other side, the traditional photovoltaic silicon-based panels are not transparent. For this reason, the solar radiation cannot penetrate inside the greenhouse. This situation causes problems in plant cultivation and desired greenhouse climate cannot be created for crops. In order to solve this problem, researchers are developing panels with partially transparent materials in flexible sheets or semitransparent rigid panels so plants can be cultivated in protected areas thanks to these developing panels which allow the passage of sunlight necessary for the plants [10].

Another type of photovoltaic is concentrated photovoltaic which provides generating electricity with limited solar cell areas. This type of PV 
coverages that provides less space on roof of greenhouses and causes homogeneous indoor illumination and uniform growth of plants. Diffuse light is more favorable than direct insolation in cases of shade plant cultivation so excess light can be utilized by concentrated photovoltaic through converting to electrical energy. Semiparent photovoltaic shade solely a fraction of the light falling on and allow maximum usage of the remnant radiation to reach the plants. Due to these reasons, it can be said that is an effective approach to balance electricity production and light transmissivity. Up to the emergence of organic photovoltaics (OPV) and later the integration of OPV to window, the real application of semi-parent photovoltaic is limited. The unique semiconductor structure of OPV provides easily manage and adjust of optimal spectral absorbance for both plants and PV modules. Nevertheless, for integration of OPV technology to modern greenhouse is still immature, not only considering higher efficiency and transparency of OPV materials but also light-weight and flexible nature for rapidly retro-fitting existing greenhouse structure make this technology attractive study area.

\subsection{CSP Greenhouse}

For Concentrating solar power (CSP) systems, direct beam solar radiation is concentrated by mirrors or lens, and thus produces forms of useful energy such as high temperature heat, electricity or fuels $[18,19]$. The direct beam component of solar radiation is kept by CSP systems while flat plate photovoltaics (PV) cannot capture diffused radiation due to clouds, dust or other factors. Solar concentration is carried out by the concentrator. This equipment collects and diffuse solar radiation to the receiver. Solar radiation is converted to high temperature heat
[18]. Furthermore, with the increasing of operating temperature and solar concentration, the receiver space area can be reduced, thus convective and conductive heat losses decrease significantly $[19,20]$. For CSP systems, the main purpose is electrical energy production. Also, these technologies provide collection and concentration of solar radiation, conversion of solar radiation into thermal energy, transport and usage of thermal energy [21]. The types of CSP systems can be divided into technologies such as parabolic trough, central receiver tower, linear Fresnel, Fresnel lenses (for CPV), paraboloidal dishes $[18,22]$.

Concentrating PV modules do not need to occupy a lot of space owing to the high efficiency. The concentration ratio of CSP is higher100 times than PV modules. On the other hand, CSP systems have a disadvantage which is overheating if the systems are not conducted well. Several concentrators are used in greenhouses like Fresnel lenses, and parabolic trough concentrators [17]. Linear Fresnel lenses is the most commonly used in greenhouse. Fresnel system have many advantage such as large amount electricity production, using relatively thin lens. For the integration of Fresnel system in greenhouse consist of a fixed Fresnel lens which collimate the direct radiation into a focal line and a tracking receiver. Thanks to Fresnel lens, direct radiation can be focused on for energy generation and diffuse light is allowed to pass into greenhouse that it used for plant growth. In addition, the efficiency of system increased by Fresnel lens. [23]. There are several experiments to recover the waste heat from concentrating PV modules and utilize as heat source in the greenhouse. These attempts both increase the electrical efficiency of PV modules and can reduce heating demand of greenhouses [17]. 
Sonneveld et al. [23] combined PV/T and linear Fresnel lenses in a greenhouse with a size of $6 \times 6 \mathrm{~m}$. These hybrid technologies used to capture all direct radiation onto the $\mathrm{PV} / \mathrm{T}$ module and the radiation was used for cultivation effectively. After conducting of this experiment, the result indicated that the thermal yield is $56 \%$ and the electric yield $11 \%$, resulting in a combined efficiency of $67 \%$ was obtained [23].

Under same weather and geometric condition Hussain et al. [27] tested linear and spot Fresnel lens for greenhouse application. The thermal efficient were 69.6 and 71.7 respectively. For Fresnel lens collector, the result of thermal efficiency and the delivered energy per unit area was 7 $12 \%$ higher than the spot Fresnel lens collector.

AALBORG is a firm which utilized central receiver solar tower system and produced heat and electricity for a greenhouse which size was $200.000 \mathrm{~m}^{2}$. The annual production of tomato was 17.000 tons. The production of heat and electricity was $20.000 \mathrm{MWh}$ heat/ year, $1.700 \mathrm{MWh} /$ year respectively. As a result of this production 4.000 tons $\mathrm{CO}_{2}$ was saved [24].

Chaoqing et al. [25] tested the changing of growth of plants under the different cover material which were glass and transparent plastic film. The system of this study consisted of a transparent entity CSP cover material $(30 \mathrm{~cm} \times 27 \mathrm{~cm}$ x $2 \mathrm{~cm}$ ), an integral box, a light meter, voltmeter, an ammeter, and so on. It is understood that the experimental and simulation result match well that the lowest transmittance is only $32 \%$, and the transmittance of cover material can reach $60 \%$ when there is strong sunshine at noon; while in the morning and afternoon.
Lishu et al. [26] conducted experiments based on hybrid system which consist of parabolic concentrated solar power system, thermoelectric hybrid power generation system (CPC-PV/TE) and flat heat pipe in greenhouse in Northeast China. In this hybrid system, thermoelectric power generator provide the conversion of heat produced to electric power. Produced power of the hybrid system range from 2.35 to 3.24 MJ and the efficiency of hybrid system which the highest value is $19.15 \%$. In addition to this hybrid system supply the necessary power for greenhouse control systems and lighting equipment.

When the non-concentrating collectors compare with Fresnel lens and other concentrating collectors, it is seen that the average thermal efficiencies are higher for Fresnel lens and other concentrating collectors due to their higher concentration ratios and lower heat losses. One of the best option for delivering energy at high temperatures is concentrating solar collectors. Also, flat plate collectors cannot achieve this situation. Thanks to concentrating solar collectors' higher temperature outputs, it more suitable for space heating, desalination and solar furnace applications. Due to its high precision, excellent optical efficiency, and low cost Fresnel lens, it is the most appropriate choice among all concentrating collectors [27]. Under summer conditions, direct radiation should be reduced as much as possible because it can affect plants negatively. In this point, CSP Fresnel lens systems is a good option for reducing direct radiation. The direct and diffuse light can be separated by Fresnel lens which can use for greenhouse [23].

\subsection{PV/T Greenhouse}

Solar batteries can convert about 18\% of the solar energy into electricity. A large part of the remaining energy is converted to heat energy, which causes 
the solar battery to overheat. Each $1^{\circ} \mathrm{C}$ temperature increasing in the solar cell reduces electricity generation by $0.45 \%$. The ideal operating temperature for solar batteries is $25^{\circ} \mathrm{C}$. In a zone with an ambient temperature is $25^{\circ} \mathrm{C}$, the panel temperature is up to $45^{\circ} \mathrm{C}$. Hybrid systems have been developed to take advantage of the heat generated by solar batteries and cool the solar cell [28]. In this way, both electricity and hot water / air are provided. The cooling of the solar battery increases the efficiency. The module is cooled by water or air channels integrated under the photovoltaic module. The water channels in the panels which are integrated with panels are circulated with the aid of pump. The energy of the heated air is transferred to water through the energy transfer unit and the heated air is used directly in the internal heating with air duct integrated system [29].

PV / T solar collectors are widely used in air and water circulation. The working principle of both is similar. Solar radiation is partly converted to electricity by photovoltaic cells with thermal adsorption in the absorber surface and the excess heat generated by the photovoltaic cells serves as the input of the thermal system. Internal heat removes from panel surface during circulation of air or water [30]. Since the photovoltaic conversion efficiency is a linearly decreasing function, the power output of solar cells is increasing with PV/T panels. Therefore, electricity and heat energy are generated from solar energy at the same time.

Total energy output of hybrid systems depends on solar energy input, ambient temperature, wind speed, operating temperature of system components and cooling mode. The efficiency of electricity is the primary goal thus effect the efficiency of hybrid system also [31].
The main advantages of this hybrid PV / $\mathrm{T}$ system are the electric and thermal energy produced by the hybrid PV / T systems is greater than discrete PV and thermal systems. It is useful due to less space coverage in roof [32]. In terms of architecture, PV / T systems on the roof are more regular than discrete PV and thermal systems [33]. The average PV temperature in a PV / T system can be lower than the temperature of a discrete PV module and thus the electrical efficiency increase. The combination of the solar cell and the solar collector in one design changes the characteristic of both.

There are many examples in the world related to $\mathrm{PV} / \mathrm{T}$ solar systems. Finocchiaro et al. [34] was designed air compact desiccant evaporative cooling system with $\mathrm{PV} / \mathrm{T}$ for residential and small buildings in Italy. The lifespan of the system is 15 years. The system has lower environmental impacts with 96\% when compared to conventional system. If this system is conducted at conventional system condition, it has same performance in cooling and heating. If water is used for circulation in this system, $2590 \mathrm{~L}$ of fresh water will be needed during a year. The electricity consumption of this system is 3 times more according to the convention system. Herrando et al. [35] studied mono-crystalline water $\mathrm{PV} / \mathrm{T}$ systems for supply of electricity and hot water of a plant in London. As a result, the PV/T system was saved up to $16.0 \mathrm{t}$ of $\mathrm{CO}_{2}$. The lifetime of system is 20 years. Thanks to this $\mathrm{PV} / \mathrm{T}$ system, the demand of $51 \%$ of electricity and $36 \%$ of hot water was meet. The efficiency of electricity production of $\mathrm{PV} / \mathrm{T}$ system is approximately $49 \%$ higher than the PVonly system. Izquierdo and de AgustínCamacho [36] applied multi-crystalline PV/T micro grid to feed a reversible airwater, $6 \mathrm{~kW}$ heating capacity heat pump in Madrid, Spain. The system saved 836 
$\mathrm{kg} \mathrm{CO}_{2}$ emissions from December to April. If the system was replaced with a natural-gas boiler, the system would be saved $574 \mathrm{~kg} \mathrm{CO}_{2}$ for December-April.

Greenhouse is one of the most effective areas where renewable energy sources can be used Greenhouse increases the quality of agricultural products and the cost of agricultural products is also increasing. Today, various heating and cooling systems are used for supplying the heating and cooling requirements in greenhouse. Heating systems are main expenditure in greenhouse [37]. Heating of greenhouse is provided by steam or hot water radiator systems, fossil fuels or electric heaters, etc. However, the heating of greenhouse is influenced drastically by the outdoor weather conditions. As mentioned before, solar energy systems which produce hot water-air or electricity by PV/T can be used separately or together. Besides, $\mathrm{PV} / \mathrm{T}$ solar energy systems are often used for hot water production and drying purposes [38]. In Turkey, PV/T solar energy is used in drying field efficiently. Turkey is a rich country in terms of solar energy. Drying of food products is mostly applied to fruits and vegetables. The drying of produced vegetables has a significant contribution to income of Turkey. For example, Turkey is ranked 4th in the world tomato production with 12.600 .000 ton/ year and the amount of exportation of tomato is $480.070 .755 \mathrm{~kg} /$ year. For this reason, tomato has an important place for export. Also, tomato is one of the most cultivating vegetable in greenhouse. Since the solar radiation in the Mediterranean region is high, it is very suitable for drying with solar energy $[39,40]$. Solar-powered drying systems have no significant costs other than initial installation and operating costs and all of the energy used is free of charge. These features can be counted among the attracting elements.
Nowadays, the drying of the products with technical methods will further increase the value in the domestic and foreign market. Drying of the products reduce the amount of moisture to certain values so that they can be stored for a long time in good quality [39].

A PV/T greenhouse dryer, integrated with PV module and DC fan is one of the most sustainable and attractive options to dry the crops using solar energy [41]. The PV module generates DC electricity, which may be used to operate the DC fan placed between air collectors and drying chamber for removal of the humid air from the greenhouse and at the same time, thermal heat of the PV module is utilized to heat air inside the greenhouse, which could help in drying of crops. PV/T solar technology in greenhouse has been studied under various cases [42]. Sodha et al. [43] explained fundamentals of the crop dryer. It includes basic of drying process, simulation model and thermal analysis with economics and market potential for drying systems. Benli and Durmuş [38] was indicated of solar air collectors and Phase Change Material (PCM), to meet the heating requirement in a greenhouse were investigated. Latent heat storage tank inside the greenhouse was filled with the PCM. The solar air collectors were used to heat and charging of PCM in the greenhouse when the solar energy was risen up in clear days. The phase change materials were discharged to profit from its energy when the heating load high cold nights in the cold weather conditions. The maximum yield in yield-time curves was found in ondulin type collectors with 43\%. Air solar collectors are available in September-December and March-May. If outdoor temperature is lower than $0{ }^{\circ} \mathrm{C}$, the indoor temperature is higher than the outdoor temperature. Janjai et al. [44] reproduced and tested greenhouse dryer with $\mathrm{PV} / \mathrm{T}$ for drying 
of peeled longan and banana. It has been observed that the drying time in the open air falls to 5-6 days. It was seen to be 3-4 days for the peeled longan and banana in the greenhouse.

Aktas et al. [39] was designed, a solar powered $10 \mathrm{~kg}$ capacity dryer manufactured and analyzed this dryer over the tomato and the dyer used under different conditions. The necessity of electricity and heat energy are provided completely by solar energy. In this study, tomatoes were dried at lower drying air temperatures except than previous studies. Since the tomatoes are sliced at a thickness of 5 $\mathrm{mm}$, mass transfer to the drying air from the product is accelerated during process. According to other studies tomatoes were dried in a shorter time. Drying practices at low temperatures prevented the heat damage that could occur in the tomatoes. Consequently, tomatoes were dried in good quality. Tiwari et al. [45,46] developed PV/T solar dryer for greenhouse with thermal model. Theoretical and experimental values of overall thermal energy found to be $1.92 \mathrm{kWh}$ and $2.03 \mathrm{kWh}$ respectively with better quality of dried product due to reduction in direct exposure of sun rays due to PV module. Tiwari et al. [47] developed and analyzed a novel type of single slope roof integrated greenhouse solar dryer under natural and forced mode without load condition. For PV/T system, overall thermal energy under natural and forced mode was found $1.84 \mathrm{~kW} \mathrm{~h}$ and $3.26 \mathrm{kWh}$, respectively. According to the result, forced mode drying is better than natural mode. Also, the thermal energy of the system decreased $76.39 \%$ and the electrical energy of the system increased $88.73 \%$ respectively with increment in packing factor of $\mathrm{PV}$ module. It was also found that with increment in mass flow rate, the thermal energy increased by $89.44 \%$ and $65.70 \%$ for natural and forced mode respectively. Patil and Gawande [48] reviewed and concluded that $\mathrm{PV} / \mathrm{T}$ solar dryers are the best choice in terms of product quality, environmental, and socio-economic point of view. Solar dryers can put on significant contribution to the rural area economy due to less payback period and low cost. In different climatic conditions the tunnel and greenhouse dryers were tested and it was shown that have shown that they are suitable to preserve vegetables, food crops and marine products. Lastly, at the view of environment, the PV/T ventilated solar tunnel greenhouse dryers are smart and reliable alternative to the natural sun drying method. Tiwari et al. [49] design of photovoltaic integrated greenhouse system has been fabricated for biogas production at IIT Delhi. The advantages of the system over other system is that it can be used with biogas heating as well as crop drying by changing the direction of air flow.

According to many experiment and research, $\mathrm{PV} / \mathrm{T}$ systems are generally used for drying products. However, $\mathrm{PV} / \mathrm{T}$ systems also produce electricity. Subsequent articles, PV/T systems should be used more effectively in order to meet the electricity needed in the greenhouses.

\section{Discussion and Conclusion}

Modern greenhouse cultivation is vital important for food demand. The biggest problem in spreading greenhouses is energy costs. Recent works clearly indicate that heating demand represents $70 \%$ to $80 \%$ of a conventional greenhouse. This is a major obstacle to sustainable production. The majority of current greenhouses utilize conventional materials on facade, and traditional technologies on heating, cooling, ventilation, air-conditioning, lighting, energy generating and storing costs of 
greenhouses to be considerably high. With integration of solar technology to modern greenhouse is aimed to reduce dependence on fossil fuels and expanding the greenhouse in places where greenhouse activities are not carried out because of environmental issues. As the energy input to the greenhouse is free and abundant, the investment provides a positive cash flow to the farmers after a particular time which is between 4 and 8 years depending on climatic conditions and crop type. Therefore, several technologies are researched for integration of solar technology to modern greenhouse.

The problem of more population and less land can be solved with photovoltaic agriculture. The photovoltaic agriculture associated with develop environment-friendly agriculture, rise of economic contribution for farm workers and significantly provide reduction of emissions.

Thanks to utilization of PV technology in agriculture provide energy conservation and environmental protection as well as promote the changeover to modern agriculture. Agricultural greenhouse which combined with PV is aimed higher agricultural income by creating a suitable environment for cultivation.

\section{References}

[1] Wang, T., Wu, G., Chen, J., Cui, P., Chen, Z., Yan, Y., Zhang, Y., Li, M., Niu, D., Li, B., Chen, H. 2017. Integration of Solar Technology to Modern Greenhouse in China: Current Status, Challenges and Prospect, Renewable and Sustainable Energy Reviews, Cilt. 70, s. 1178-1188.

[2] Nicholls, C., Altieri, M. 2012. Plant Biodiversity Enhances bees and Other Insect Pollinators in Agroecosystems - A Review,
Agronomy for a Sustainable Development, Cilt. 33, s. 257-274.

[3] Yano, A., Onoe, M., Nakata, J. 2014. Prototype Semi-Transparent Photovoltaic Modules for Greenhouse Roof Applications, Biosystems Engineering, Cilt. 122, s. 62-73.

[4] Manitoba, Greenhouse Energy Calculations: A Cost Comparison of Different Energy Sources for Heating A Greenhouse, https://www.gov.mb.ca/agricultur e/crops/production/print,energycalculations.html (Accessed:14.04 2017)

[5] Emam Hassanien, R.H., Li, M., Lin, W.W. 2016. Advanced Applications of Solar Energy in Agricultural Greenhouses, Renewable and Sustainable Energy Reviews, Cilt. 54, s. 989-1001.

[6] Canakci, M., Emekli, N.Y., Bilgin, S., Caglayan, N. 2013. Heating Requirement and Its Costs in Greenhouse Structures: A Case Study for Mediterranean Region of Turkey, Renewable and Sustainable Energy Reviews, Cilt. 26, s. 483-490.

[7] Tong, Y., Kozai, T., Nishioka, N., Ohyama., K. 2012. Reductions in Energy Consumption and CO2 Emissions for Greenhouses Heated with Heat Pumps, Trans ASABE, Cilt. 28, s. 401-406. DOI: $10.13031 / 2013.41488$

[8] The Greenhouses of Almeria. 2013.http://www.amusingplanet.c om/2013/08/the-greenhouses-ofalmeria.html (Accessed:14.04. 2017)

[9] Marucci, A., Gusman, A., Pagniello, B., and Cappuccini, A. 2013. Solar Radiation Inside Greenhouses Covered with Semitransparent Photovoltaic Film: First Experimental Results, Journal of Agricultural Engineering, s. 44-49. DOI: 10.4081/jae.2013.s2.e49 
[10] Marucci, A., Monarca, D., Cecchini, M., Colantoni, A., Manzo, A., Cappuccini, A. 2012. The Semitransparent Photovoltaic Films for Mediterranean Greenhouse: A New Sustainable Technology, Mathematical Problems in Engineering, Cilt. 2012, s. 14. http://dx.doi.org/10.1155/2012/4 51934

[11] Xue, J. 2017. Photovoltaic Agriculture - New Opportunity for Photovoltaic Applications in China, Renewable and Sustainable Energy Reviews, Cilt. 73, s. 1-9.

[12] Renewable Energy Policy Network for the 21st Century. 2016. http://www.ren21.net/wpcontent/uploads/2016/10/REN21 _GSR2016_FullReport_en_11.pdf (Accessed: 10.04. 2017)

[13] Kadowaki, M., Yano, A., Ishizu, F., Tanaka, T., Noda, S. 2012. Effects of Greenhouse Photovoltaic Array Shading On Welsh Onion Growth, Biosystems Engineering, Cilt. 111, s. 290-297.

[14] Ureña-Sánchez, R., Callejón-Ferre, ÁJ., Pérez-Alonso, J., and CarreñoOrtega, Á. 2012. Greenhouse tomato production with electricity generation by roof-mounted flexible solar panels, Scientia Agricola, Cilt. 69, s. 233-9. http://dx.doi.org/10.1590/S010390162012000400001 (Accessed April 10, 2017)

[15] Yano, A., Kadowaki, M., Furue, A., Tamaki, N., Tanaka, T., Hiraki, E., Kato, Y., Ishizu, F., Noda, S. 2010. Shading and Electrical Features of a Photovoltaic Array Mounted Inside the Roof of an Eastewest Oriented Greenhouse, Biosystems Engineering, Cilt. 106, s. 367-377.

[16] Cossu, M., Murgia, L., Ledda, L., Deligios, P.A., Sirigu, A., Chessa, F., and Pazzona, A. 2014. Solar radiation distribution inside a greenhouse with south-oriented photovoltaic roofs and effects on crop productivity, Applied Energy, Cilt. 133, s. 89-100.

[17] Cuce, E., Harjunowibowo. D., and Mert Cuce, P. 2016. Renewable and Sustainable Energy Saving Strategies for Greenhouse Systems: A Comprehensive Review, Renewable and Sustainable Energy Reviews, Cilt. 64, s. 34-59.

[18] Lovegrove, K., Stein, W. 2012. Concentrating Solar Power Technology Principles, Developments and Applications, USA: Woodhead Publishing Limited, 704s.

[19] Fuqiang, W., Ziming, C., Jianyu, T., Yuan, Y., Yong, S., Linhua, L. 2017. Progress in concentrated solar power technology with parabolic trough collector system: A comprehensive review, Renewable and Sustainable Energy Reviews, Cilt. 79, s. 1314-1328.

[20] Goswami, D.Y., Kreith, F. 2007. Handbook of Energy Efficiency and Renewable Energy, Taylor \& Francis Group, LLC, 1560s.

[21] Lorenzini, G., Biserni, C., Flacco, G. 2010. Solar Thermal and Biomass Energy, UK: WIT Press, 224s.

[22] Kumar, A., Prakash, O., Dube, A. 2017. A review on progress of concentrated solar power in India, Renewable and Sustainable Energy Reviews, Cilt. 79, s. 304-307.

[23] Sonneveld, P.J., Swinkels, G.L.A.M., van Tuijl, B.A.J., Janssen, H.J.J, Campen, J., Bot, G.P.A. 2011. Performance of A Concentrated Photovoltaic Energy System with Static Linear Fresnel Lenses, Solar Energy, Cilt. 85, s. 432-442.

[24] AALBORG CSP. 2017. http://www.aalborgcsp.com/proje cts/integrated-energy-systembased-on-csp-australia (Accessed: 17.04. 2017) 
[25] Chaoqing, F., Hongfei, Z., Rui, W. 2014. Development of Transparent Greenhouse Cover with Function of Generating Electricity by Surplus Light and Photovoltaic, Transactions of The Chinese Society of Agricultural Engineering, Cilt. 30, s. 135-141.

[26] Lishu, W., Lin, L., Qiuyan, L., Xiuzeng, D., Bolin, W. 2015. Design and performance test of CPCPV/TE hybrid power generation system in greenhouse, Transactions of the Chinese Society of Agricultural Engineering, Cilt. 31, s. 8-15.

[27] Hussain, M.I., Ali, A., Lee, G.H. 2015. Performance and economic analyses of linear and spot Fresnel lens solar collectors used for greenhouse heating in South Korea, Energy, Cilt. 90, s. 1522-1531.

[28] Huang, B.J., Lin, T.H., Hung, W.C., Sun, F.S. 2001. Performance Evaluation of Solar Photovoltaic/Thermal Systems, Solar Energy, Cilt. 70, s. 443-448.

[29] Daghigh, M., Ruslan, H., Sopian, K. 2011. Advances in Liquid Based Photovotaic/Thermal (PV/T) Collectors, Renewable and Sustainable Energy Reviews, Cilt. 15, s. 4156-4170.

[30] Anand, S., Tiwari, A. 2006. Energy and exergy efficiencies of a hybrid photovoltaic-thermal (PV/T) air collector, Centre for Energy Studies, Indian Institute of Technology Delhi

[31] Erkaya, K., Çolak, M. 1998. Fotovoltaik-Fototermik Dönüştürücülerde Verim Optimizasyonu. Ege Üniversitesi Güneş Enerjisi A.B.D., Fen Bilimleri Enstitüsü, Doktora Tezi, E.Ü., 150s, İzmir.

[32] Engin, D., Çolak M. 2008. YarıSaydam Güneş Pili/Termal Toplayıcı (pv/t) Hibrid Sistemin İzmir Kosullarinda Analizi, Celal
Bayar Üniversitesi, Soma Meslek Yüksek Okulu Teknik Bilimler, Cilt. 2, sayi:10.

[33] Zondag, H.A., de Vries, D.W., van Helden, W.G.J., van Zolingen, R.J.C., van Steenhowen, A.A. 2002. The Thermal and Electrical Yield of a PV-thermal Collector, Solar Energy, Cilt. 72, s. 113-128.

[34] Finocchiaro, P., Beccali, M., Cellura, M., Guarino, F., Longo, S. 2016. Life Cycle Assessment of A Compact Desiccant Evaporative Cooling System: The Case Study of The "Freescoo", Sol. Energy Mater., Cilt. 156, s. 83-91.

[35] Herrando, M., Markides, C.N., Hellgardt, K. 2014. Appl. Energy, Cilt. 122, s. 288-309.

[36] Izquierdo, M., de Agustín-Camacho, P. 2015. Solar Heating by Radiant Floor: Experimental Results and Emission Reduction Obtained with a Micro Photovoltaice Heat Pump System, Appl. Energy, Cilt. 147, s. 297-307.

[37] Ertekin, C., Bilgili, E. 1998. Guneș Enerjili Hava Isıtıcılarında Isıl Verim, 5. Ulusal Soğutma ve İklimlendirme Tekniği Kongresi, Adana, s. 237-248.

[38] Benli, H., Durmuş, H. 2007. Havalı Güneş Kolektörleri ve Gizli Isı Depolama Yöntemi Kullanılarak Sera Isitılması, Mühendis ve Makina, Cilt. 48, Sayı: 569.

[39] Aktaş, M., Şevik, S., Doğan, H., Öztürk, M. 2013. Fotovoltaik ve Termal Güneş Enerjili Sürekli Bir Kurutucuda Domates Kurutulması, Journal of agricultural sciences, Cilt. 18, s. 287-298.

[40] Ceylan, I., Aktaş, M., Doğan, H. 2006. Güneş Enerjili Kurutma Fırınında Elma Kurutulması, Journal of Polytechnic, Cilt. 9, s. 289-294.

[41] Tiwari, G.N., Sharma, P.K., Goyal, R.K., Sutur, R.F. 1998. Estimation of Efficiency Factor for a Greenhouse: A Numerical and Experimental 
Study, Energy and Buildings; Cilt. 28, s. 241-250.

[42] Barnwal, P., Tiwari, A. 2008. Design, Construction and Testing of Hybrid Photovoltaic Integrated Greenhouse Dryer. International Journal of Agricultural Research (IJAR), Cilt. 3, s. 110-120.

[43] Sodha, M.S., Bansal, N.K., Kumar, A., Bansal, P.K., Malik, M.A.S. 1987. Solar Crop Drying, CRC Press, 1st Edn, Cleveland, Ohio.

[44] Janjai, S., Lamlert, N., Intawee, P., Mahayothee, B., Bala, B.K., Nagle, M. 2009. Experimental and Simulated Performance of a PV-Ventilated Solar Greenhouse Dryer for Drying of Peeled Longan and Banana., Sol. Energy, Cilt. 83, s. 1550-1565.

[45] Tiwari, S., Tiwari, G.N., Al-Helal, I.M. 2016a. Performance Analysis of Photovoltaic-Thermal (PVT) Mixed
Mode Greenhouse Solar Dryer, Sol. Energy, Cilt. 133, s. 421-428.

[46] Tiwari, S., Tiwari, G.N., Al-Helal, I.M. 2016b. Development and Recent Trends in Greenhouse Dryer: a revie, Renew. Sustain. Energy Rev., Cilt. 65, s. 1048-1064.

[47] Tiwari, S., Tiwari, G.N. 2016. Thermal Analysis of PhotovoltaicThermal (PVT) Single Slope Roof Integrated Greenhouse Solar Dryer, Solar Energy, Cilt. 138, s. 128-136.

[48] Patil, R., Gawande, R. 2016. A review on Solar Tunnel Greenhouse Drying System, Renew Sustain Energy Rev; Cilt. 56, s. 196214.

[49] Tiwari, S., Bhatti, J., Tiwari, G.N., AlHelal, I.M. 2016. Thermal Modelling of Photovoltaic Thermal (PVT) Integrated Greenhouse System for Biogas Heatings, Solar Energy, Cilt. 136, s. 639-649. 